\title{
Pedological Characterization of the Soils of Atbara and Gash Rivers Upper Atbara Project Area (Kassala State - Sudan)
}

\author{
El Abbas. Doka M. Ali ${ }^{1}$, Neil R. Munro ${ }^{2}$ and Karl Peter Kucera ${ }^{3}$ \\ ${ }^{1}$ Land Resources Consultant, College of Agricultural Studies, Sudan University of \\ Science and Technology, Shambat. \\ ${ }^{2}$ International Consultant, Soil Survey and Land Evaluation. \\ ${ }^{3}$ International Consultant, Soil Survey and Land Evaluation. \\ adoka21@gmail.com; Neil.munro@dial.pipex.com; KpKucera@gmail.com
}

\begin{abstract}
The soil study area is composed of wide and nearly flat alluvium plain deposits laid by Atbara and Gash Rivers. The study area makes about 751,290 ha and lies within arid and semi-desert climate zones and experiences rainfall in the order of $100 \mathrm{~mm}$ in its northern edge, increasing to some $400 \mathrm{~mm}$ at its southern boundary close to Kassala and east of New Halfa town. The soil study was based mainly on a semi-detailed level soil surveys and the key specifications are a field density of 1 observation each 150 ha. Previously published soil study information was reviewed and incorporated in the findings [5[; [17]; [14].
\end{abstract}

The Aridisols and Entisols in eastern region of Sudan have high potential for crop production, but some constraints emerge affecting crop performance and decreasing yields. Those limitations are aspects of climatic conditions, parent materials and topography manifested generally in, 1) soil moisture deficiency and locally in; 2 ) accumulation of secondary salts 3 ) clayey topsoil textures. Aridisols are the soils of arid regions that exhibit at least some subsurface horizon development. They are characterized by being dry most of the year and limited leaching. Aridisols contain subsurface horizons in which clays, calcium carbonate, silica, salts, and/or gypsum have accumulated. Aridisols in their natural state are used mainly for range, wildlife, and recreation. Because of the dry climate in which they are found, they are not used for agricultural production unless irrigation water is available. Entisols formed by rapid deposition on floodplains are universally favored for growing food crops in large part because of the influx of fertility in the deposited material, their level topography, and often the proximity to transportation and water afforded by adjacent rivers. In aridic (torric) soil moisture regimes their alluvial deposits close to rivers are more easily irrigated than associated soils on adjacent higher terraces or the far away finer clayey deposits.

Many, if not most of these areas are subject to flooding and often have extremely abrupt textural differences (i.e. stratifications) engendered by sedimentation processes. In floodplains the river channels migrate as the watershed characteristics change leaving sandy and silty sediments (levees) near the riverbank and finer textured materials further from the riverbank. In aridic moisture conditions Entisols on depressional areas or at higher terraces close to Aridisols are subject to salt accumulation similar to Aridisols. To minimize the concurrence of hazards in Aridisols and Entisols, management procedures should adhere to land and crop management systems. As well, the fertility status is likely to decline due to intensive farming of some nutrient-depleting crops, but this nutrient 
El Abbas. Doka M. Ali, Neil R. Munro and Karl Peter Kucera; Pedological Characterization of the Soils of Atbara and Gash Rivers Upper Atbara Project Area (Kassala State - Sudan). Advances in Image and Video Processing, Volume 5 No 6, December (2017); pp: 19-32

deficiency is correctable through implementing a fertilizer programme. In the study area, some parameters are management-factors determining e.g. topsoil textures and flat slope favoring uniform distribution of irrigation water through well designed irrigation and drainage network. Those technical inputs if properly used and practiced are expected to sustain crop production.

Key words: Aridisols, Entisols, Atbara and Gash Rivers, Alluvium deposits

\section{Introduction}

The Upper Atbara study area is situated between Atbara River in the west and Gash River in the east with a total area of 751,290 ha. The area lies north of the asphalt road connecting Kassala and Khashm El Girba towns and extend northward further to north of Goz Ragab, Jebel Ufrek and Hadaliyah. As well along the eastern border of the area runs the highway which connects Kassala to Port Sudan. The area is nearly flat with relatively few water channels dissections in the south and predominantly windblown features in middle and northern parts. Khashm El Girba Irrigated scheme lies to the west of this area across River Atbara. The Gash River Delta which borders the area to the west comprises a large seasonal irrigated farming area (Gash Agricultural project). Figure 1 shows the location of the study areas [5].

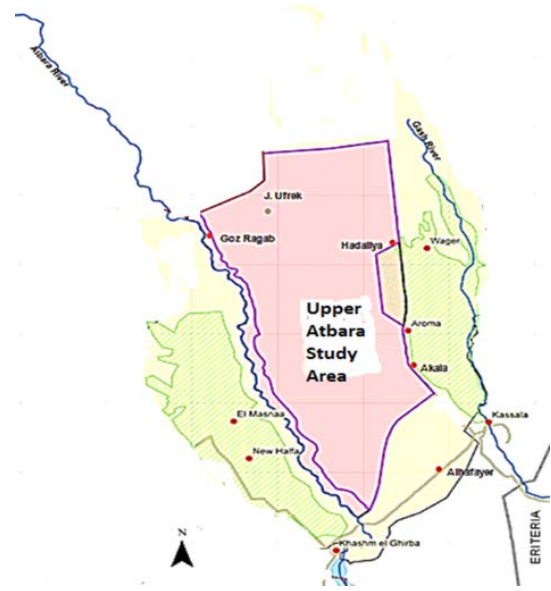

Figure 1: Location Map of Upper Atbara Study area. The map shows Atbara River, Gash River, New Halfa and Gash Delta Agriculture areas (Modified from [5])

Recent climatic maps showing the different climatic regimes in Sudan were produced based on the Papadakis climatic classification by [24]. The climatic zones (Figure 2) are based primarily on the water balance, using monthly rainfall and potential evapotranspiration data (Penman formula). The differentiating criteria are significant for agriculture, whilst the zones also correspond with natural vegetation zones. In this context two main climatic zones are defined, in which the climate of the northern parts of the study areas lie in the semi-desert zone (D3.1 or Zone 5) represented by Aroma Met station whereas the southern parts lie in the arid zone (A1.1 or Zone 4) represented by Kassala and New Halfa Met stations [25[; [9]. The following is a brief descriptive account of the main climatic parameters (Figure 2 and Table 1). At zone 4 the mean maximum temperatures of the hottest month (April and May) are 40.9-41.5 oC; whilst the mean minimum temperatures of the coldest month (December and January) are 16.5-18.8 Co. They are followed by a general rise of temperature in February and March. In summer the maximum exceeds 45 Co imposing extreme conditions of heat and dryness affecting the perennial vegetation, and the minimum is at 33-35 Co. At zone 5 the mean maximum temperatures of the hottest month (April and May) are 41.2-42.1 oC; whilst the mean minimum temperatures of the coldest month (December and January) are 14.3-15.6 Co. At both zones 
December and January are followed by a general rise of temperature in February and March. In summer the maximum temperature slightly exceeds 45 Co imposing extreme conditions of heat and dryness affecting the perennial vegetation, and the minimum is at 33-35 Co. These conditions are relieved by the first rains of the new season.

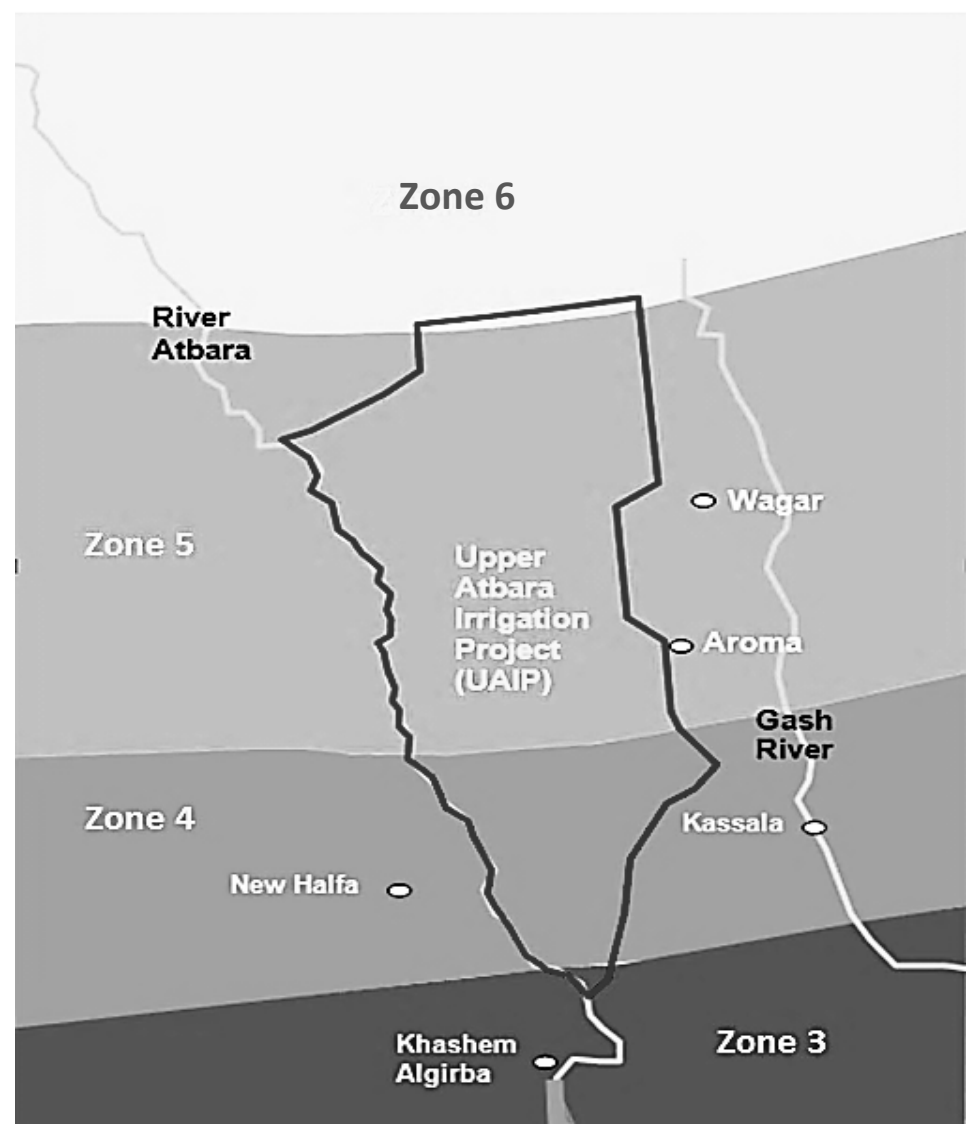

Figure 2: Climatic Zones 3, 4, 5 and 6 at Study area ([24] and [9])

The rainfall of the study area, being an integrated part of the central clay plain of the Sudan lies mainly within the arid and semi-desert climates (A1.1 and D3.1) of [24) and associated with the West Africa monsoon system, derived from South Atlantic and Congo air masses, with some Indian Ocean influence. The average annual total rainfall is about 235 and $175 \mathrm{~mm}$ at zone 4 and 5 respectively which falls mainly in the months of June-September, and is less than 44 per cent of the annual potential evapotranspiration. All the months are dry since the average rainfall never exceeds the potential evapotranspiration. Relative humidity being 25-60\% and $25 \%$ - 50 during most of the year rises to 70 per cent in the rainy season. As represented by Kassala and Aroma meteorological stations, the evapotranspiration exceeds the annual monthly rainfall indicating the dry conditions of the climate throughout Study area. This indicates that there is no humid month at study area and irrigated farming should be considered in the area. Supplementary irrigation might be possible during rainy season especially on slightly depressional or receiving sites. 
El Abbas. Doka M. Ali, Neil R. Munro and Karl Peter Kucera; Pedological Characterization of the Soils of Atbara and Gash Rivers Upper Atbara Project Area (Kassala State - Sudan). Advances in Image and Video Processing, Volume 5 No 6, December (2017); pp: 19-32

Table 1: Monthly Rainfall and ETo in Zone 4 and 5 in Upper Atbara Irrigation Study area

\begin{tabular}{|c|c|c|c|c|c|c|c|c|c|c|c|c|c|c|}
\hline Zone & $(\mathrm{mm})$ & Jan & Feb & Mar & Apr & May & Jun & Jul & Aug & Sep & Oct & Nov & Dec & Yearly \\
\hline \multirow{5}{*}{\begin{tabular}{l}
\multicolumn{1}{c}{4} \\
Southern \\
Parts of \\
STUDY \\
AREA \\
(A1.1) \\
Kassala
\end{tabular}} & $\begin{array}{l}\text { ETo } \\
\text { (mm/ } \\
\text { month) }\end{array}$ & 180 & 193 & 248 & 255 & 263 & 264 & 236 & 211 & 207 & 223 & 207 & 195 & 2682 \\
\hline & $\begin{array}{l}\text { Mean } \\
\text { Monthly } \\
\text { Rainfall }\end{array}$ & 0 & 0 & 0 & 2.1 & 11 & 24.4 & 67.6 & 81.9 & 39.2 & 8.6 & 0.2 & 0.0 & 235.0 \\
\hline & $\begin{array}{l}\text { Wind } \\
\text { Prev. } \\
\text { Direction }\end{array}$ & $\mathrm{N}$ & $\mathrm{N}$ & $\mathrm{N}$ & $\mathrm{N}$ & $\mathrm{N}$ & $S$ & S & S & S & $S$ & $\mathrm{~N}$ & $\mathrm{~N}$ & --- \\
\hline & $\begin{array}{l}\text { Wind } \\
\text { Mean } \\
\text { speed } \\
\text { Km/H }\end{array}$ & 9 & 10 & 10 & 9 & 9 & 12 & 14 & 13 & 10 & 9 & 10 & 11 & 10 \\
\hline & R.H. \% & 45 & 39 & 31 & 27 & 30 & 38 & 54 & 60 & 53 & 40 & 39 & 45 & 42 \\
\hline \multirow{5}{*}{$\begin{array}{c}5 \\
\text { Northern } \\
\text { Parts of } \\
\text { STUDY } \\
\text { AREA } \\
\text { (D3.1) } \\
\text { Aroma }\end{array}$} & $\begin{array}{l}\text { ETo (mm/ } \\
\text { month) }\end{array}$ & 127 & 137 & 186 & 189 & 195 & 204 & 192 & 183 & 171 & 158 & 144 & 130 & 2,017 \\
\hline & $\begin{array}{l}\text { Mean } \\
\text { Monthly } \\
\text { Rainfall }\end{array}$ & 0.6 & 0.0 & 0.0 & 2.5 & 9.1 & 16.8 & 58.8 & 51.9 & 26.3 & 6.2 & 0.8 & 0.0 & 173 \\
\hline & $\begin{array}{l}\text { Wind } \\
\text { Prev. } \\
\text { Direction }\end{array}$ & $\mathrm{NE}$ & $\mathrm{NE}$ & $\mathrm{NE}$ & $\mathrm{N}$ & S & S & S & S & S & $\mathrm{NE}$ & $\mathrm{NE}$ & $\mathrm{NE}$ & -- \\
\hline & $\begin{array}{l}\text { Wind } \\
\text { Mean } \\
\text { speed } \\
\text { Km/H }\end{array}$ & 4 & 4 & 5 & 4 & 4 & 6 & 6 & 5 & 4 & 3 & 4 & 4 & 4.4 \\
\hline & R.H. \% & 46 & 39 & 32 & 25 & 25 & 30 & 44 & 49 & 46 & 36 & 38 & 44 & 38 \\
\hline \multirow{5}{*}{$\begin{array}{c}4 \\
\text { Southern } \\
\text { Western } \\
\text { Parts of } \\
\text { STUDY } \\
\text { AREA } \\
\text { (A1.1) } \\
\text { New Halfa }\end{array}$} & $\begin{array}{l}\text { ETo (mm/ } \\
\text { month) }\end{array}$ & 298 & 196 & 254 & 273 & 267 & 276 & 239 & 211 & 207 & 192 & 189 & 171 & 2772 \\
\hline & $\begin{array}{l}\text { Mean } \\
\text { Monthly } \\
\text { Rainfall } \\
\end{array}$ & 0.1 & 0.0 & 0.0 & 2.8 & 14.7 & 22.3 & 74.2 & 94.3 & 36.1 & 4.3 & 0.6 & 0.0 & 249.5 \\
\hline & $\begin{array}{l}\text { Wind } \\
\text { Prev. } \\
\text { Direction }\end{array}$ & $\mathrm{N}$ & $\mathrm{N}$ & $\mathrm{N}$ & $\mathrm{N}$ & SW & SW & SW & SW & SW & $\mathrm{N}$ & $\mathrm{N}$ & $\mathrm{N}$ & --- \\
\hline & $\begin{array}{l}\text { Wind } \\
\text { Mean } \\
\text { speed } \\
\text { Km/H }\end{array}$ & 10 & 10 & 10 & 10 & 9 & 12 & 13 & 11 & 9 & 6 & 8 & 8 & 10 \\
\hline & R.H. \% & 41 & 34 & 27 & 23 & 25 & 33 & 49 & 54 & 49 & 38 & 37 & 40 & 38 \\
\hline
\end{tabular}

(Source: Sudan Meteorological Authority Database 1971- 2000)

The study area is flat with a reasonably constant gradient however, there are localized depressions and several shallow drainage systems running from east to west in which water ponds during and after the rainy season, particularly in the southern part of the area. Elevation decreases from approximately 475 meters above sea level (masl) at the southern boundary to approximately 400 amsl at the northern boundary, with an overall gradient of approximately $0.5 \mathrm{~m}$ per kilometer, but with a higher gradient in the southern half (approx. $0.8 \mathrm{~m} / \mathrm{km}$ ), and lower gradient in the north (approx. $0.3 \mathrm{~m} / \mathrm{km}$ ).

The study area is characterized by soils derived from two major geomorphologic units, namely the Gash River fan and Atbara Flood Plain [19];[20];[21];[22]; [12]. The Gash River fan can be subdivided into Very Old Gash Fan, Old Gash Fan and Sub Recent Gash Fan. Soils of the Sub Recent Gash Fan (Gash delta) overlie older Gash fan deposits and exhibit layering associated with sub recent and recent fluvial processes [6] Gash River is an intermittent river that floods annually and provides fresh sediment in active flood zones and through flash flooding. Flows in the Gash River have high velocity during peaks of rainy season and the river forms many channels, which can be clearly seen on the satellite imagery. According to our field experience, flooding of Gash River sometime reaches as far as Hadaliyah settlement and in several locations also floods land adjacent to the main north south road [23]; [5].. 
The Atbara Plain consists of two major units namely heavily dissected kerrib terrace and Atbara Alluvial Plain with localized depressions generally adjacent to the kerrib deposits [27]. Since the commissioning of the Tekeze Dam in Ethiopia the Atbara River flows now throughout the year, and since the construction of the Khashm el Girba dam does not seem to cause regular flooding. Flooding or inundation takes place only as a backup behind the kerrib deposits for short periods during heavy rainfall events during the rainy season. Atbara plains consist of very flat terrain $(<1 \%)$ with some buried channels. The Atbara River is confined to a channel formed by kerrib lands - former levees and terraces that form prominent highly dissected physiographic feature of the area landscape. This unit is elevated above the general level of the former flood plain and highly dissected through gully and rill erosion. There are some localized flat sections of the terraces suitable for smallholder pump irrigation for production of vegetables and fruits.

\section{Natural vegetation and Present land use}

The plant community in study area consists of a mix of Acacia tortilis(Samr), Acacia raddiana(Seiyal), and Acacia mellifera(Kitr), withscattered Acacia nubica(Laot),Balanitesaegyptiaca(Heglig),Capparis decidua (spinosa) (Tundub), Bosciasenegalensis(Mokheit)and open areas of grasses and herbs. Acacia tortilis and Acacia raddiana are continuously being browsed by camels and goats and because of this they are not destroyed. Balanitesaegyptiaca is widespread in the area forming parkland. The most abundant grasses include Aristidamutaiblis, Aristidapallida, Cenchrusbiflorus, Maeruacrassifolia and Cymbopogon proximus [15] and [5]). The Vegetation on floors of water channels includes large trees of Acacia ehrenbergiana(Salam),Capparis decidua(Tundub) and Acacia raddiana(Seiyal).At the Kerrib land Acacia nilotica (Sunt), Acacia nubica (Laot), Acacia raddiana (Seyal) are the most abundant species.Some parts of the study area have sporadicrainfed farming, mostly sorghum. Much of this is undertaken villagers from surrounding villages. A considerable number of grazing animals and nomadic tribes were noticed all over the area and most probably they come at the end of the rainy seasons to look for water which is retained in Hafirs for quite some time.

\section{Materials and Methods}

A total of 4328 augers and 379 profile pits were made (Figure 3). The locations of all pit and auger sites are demarcated on Landsat images. These locations are based on GPS co-ordinates and shown on figure 3. Field recording of soil auger sites and soil profiles was on standardized proformas and soils were described following the [8] "Guidelines for Soil Description". The observations included [5]:

- $\quad$ Auger number; Surveyor; Date; GPS co-ordinates; Landform; Topography; Slope; Site; Surface Features; Termitaria; Trees; Shrubs; Land Use; Water-table; Soil drainage class; Samples; Soil type; Depth of cracking; Soil code; Soil horizons (for each: boundary, colour, colour code, mottles, texture class, cracks, clay skins, slickensides, coarse fragments, reaction to dilute hydrochloric acid, calcium carbonates, iron-manganese, gypsum, and other recorded features).At all auger sites soil samples were collected from the 0.0-0.3, 0.3-0.6 and 0.6-0.9 m depths, for $\mathrm{pH}$, salinity (EC) and sodicity (SAR) screening. 


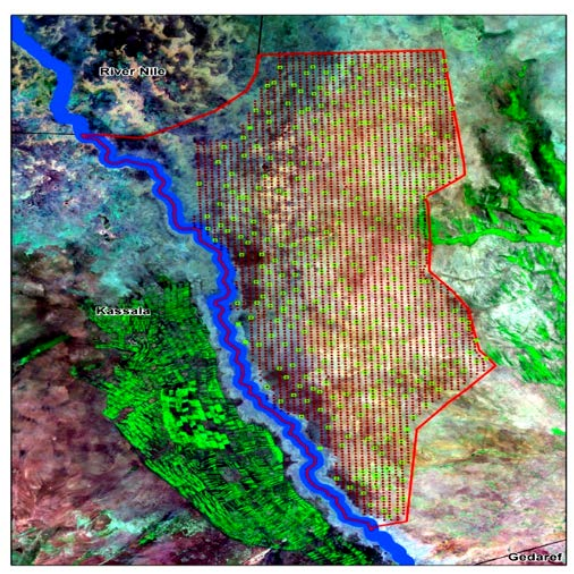

(Source: DIU 2014)

Figure 3: Sites of Soil Augers (Red dots) and Profile Pit Observations (Green squares) in study Area that are Demarcated on Landsat (October 2007).

\section{Results and Discussions}

\subsection{ARIDISOLS}

\subsubsection{Surface Features and Morphological Properties}

Aridisols are the dry soils of arid climates (the root arid or id comes from the Latin aridus for dry). In the study area during rainy season they receive enough rain to permit rainfed agriculture. They may have clay enriched subsoil and /or cemented to non-cemented deposits of salts or carbonates. Salinization or salt build up should be observed when using Aridisols for irrigated agriculture. A typical horizon sequence would be A, Bk, C. The diagnostic features are an ochric epipedon and an argillic, cambic, calcic or gypsic subsurface horizon (Figure 4).

\subsubsection{Surface mulch and/or sealing}

The surface mulch comprises fine and medium sized granules $(2-5 \mathrm{~mm})$ occasionally obscuring surface cracks in depressional areas. It is the first surface feature to be identified on the soils of the study area, and varies in thickness between $10-50 \mathrm{~mm}$. The mulch is a water-conserving feature reflecting beneficial agronomic practices, such as harvesting of groundnuts, tubers and shallow-rooted vegetable and growing of food grain (sorghum and millet). Such cropped areas are relatively more in southern parts of study area. In irrigated farming, sprinkler irrigation may be more satisfactory because it would make gradual wetting possible and offers the possibility of structural improvement [11]. However, some of the fine textures do not form mulch on drying but produce "crusty surface". These crusty surface soils are commonly found in depressions or shedding sites. Surface runoff and wind erosion on sloping areas produced such sealed surfaces. 


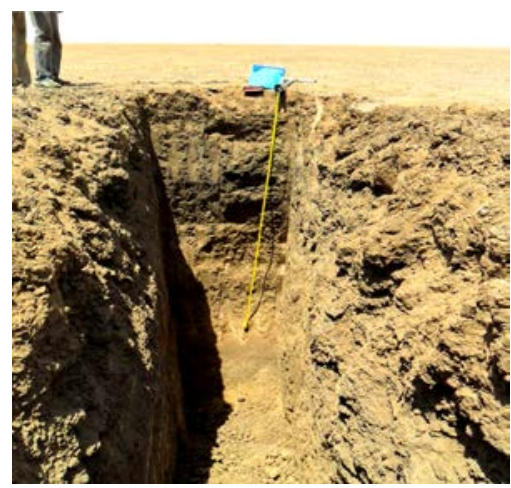

Figure 4: Aridisol profile (Vertic Haplocambids) at Study area

\subsection{Aridic and Cambic properties}

A surficial or near surface crust; a pavement of embedded and loose pebbles or of stones with a black to reddish brown desert varnish; shrinkage polygons, locally with the appearance of slick spots (takyr), with cracks continuing to or into the B horizon. Stratified and homogenized subsoils are common with variable topsoil textures (Figure 5). Water deficiency under natural conditions, is a problem, at times, in all Aridisols because taxonomic criteria dictate that they must have a layer characterized by salt accumulation ([16] and [17].A typical Aridisol has an even surface topography; with a thin surface mulch or sealed surfaces. Topsoil structures are moderate to strong with dominantly medium size subangular blocks. In Study area the Aridisols consist of flat mostly sealed surface in a continuous pattern of flat plains, or slightly raised areas with this mulchy surface masking the topsoil fissures and cracks. Several hypotheses have been put forward to explain the genesis and formation of Aridisols. These have in common that they relate most of their morphological features to the aridic moisture regime. They pointed out that they have some degree of soil formation in subsurfacehorizon (cambic horizon or stronger). Other important features include very limited amount of organic matter in topsoil (ochric epipedon) and a rearrangement in soil profile of more or less soluble salts (chlorides, sulphates, carbonates, silicates) into weak or strong, soft or cemmented forms (calcareous, calcic, petrocalcic,etc.). The soils may or may not have a degree of pedogenic textural differentiation (argillic horizon).

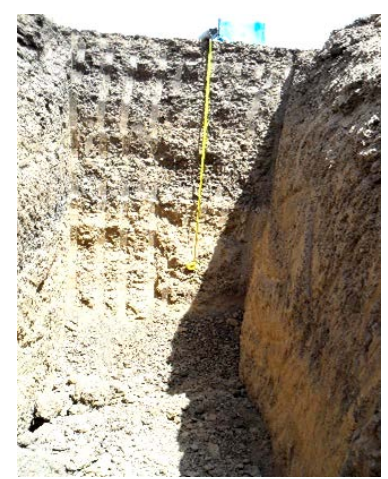

(A) Stratified with heavy texture topsoil

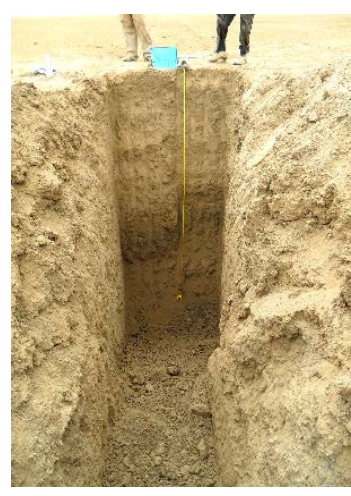

(B) Stratified with medium texture topsoil

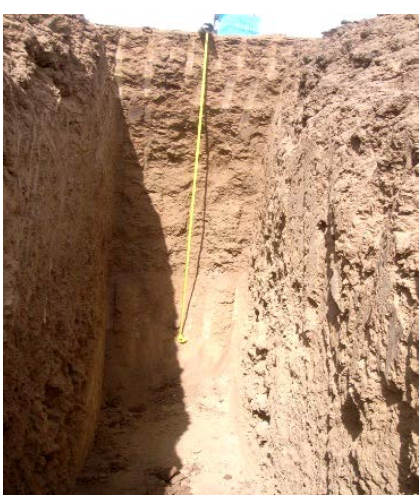

(C) Homogenized top and subsoil

Figure 5: Soil stratifications and homogenization in some profiles at Study area Structure and other profile features(Source: [5]) 


\subsubsection{Mineral concretions and aggregates}

$\mathrm{CaCO} 3$ concretions and other forms of pedogenic carbonate have been described in profiles at the central and northern parts of Sudan [4]. In Aridisols the carbonate concentrations have been differentiated into types based on their appearance in thin sections. Carbonate has also been described from stereomicroscopic observation of undisturbed soil fragments and wet-sieved fractions over $0.5 \mathrm{~mm}$ and in soil profile walls. X-ray diffraction shows that in all samples the carbonate mineral is calcite [1]; [2]. Soft, powdery types of carbonate are diffused nodules or channel neo-calcitants; hard, discrete types are generally nodules, sometimes concretions, septaria and pedodes (Figure 6). The hard types have been differentiated on the presence and form of "impregnations" by iron and manganese (dendrites of manganese, neo- or quasiferans) and of cutans (generally manganese). Often there is a relation between types of pedogenetic carbonate present and other profile characteristics. Soft, powdery types appear to have formed in situ. Hard, discrete types in the accretion of the carbonate and formation of "impregnations" and cutans are due to processes which are - or have been- active in the lower part of the profile.

\subsubsection{Physical properties}

All soils are $>2.0 \mathrm{~m}$ deep*. The Aridisols clay varies in depth from 2 to $<4.0 \mathrm{~m}$. The strata at the surface are heterogeneous brown, dark brown or dark yellowish brown silty clays, clay loams or sandy clay loams. Infiltration rate (permeability) and hydraulic conductivity tests were carried in the field. The values for untested (AWC) parameters were extracted from [10]. The infiltration tests were conducted in the study area using double ring infiltrometers. The values represent the basic infiltration rates which show almost consistent trends of $1.4 \mathrm{~cm} / \mathrm{h}$ due to the behaviour of the homogenous soils of the study area. The optimum basic infiltration rates for surface irrigation are considered to be in the range of 0.7 to $3.5 \mathrm{~cm} / \mathrm{h}$, although acceptable normal values range from about 0.3 to $6.5 \mathrm{~cm} / \mathrm{h},[10]$. However, it is reported that the methods of infiltration measurement can suffer from a number of errors including, lack of adequate pre-wetting of dry clayey topsoil that need weeks of pre-wetting before fissures and cracks are closed; and soil disturbance effects due to mulchy surfaces which may alter the soil - water intake characteristics.

\subsubsection{Chemical and Mineralogical properties}

It is assumed that the vertic (high clay content) or non vertic (Typic) Aridisols of any soil unit will have a similar chemistry to that soil unit since subsoil the control section determines the soil class and the topsoil. The soil particle size analysis recorded clay content in the range of $30-60 \%$ that belongs to the clayey and fine loamy classes in the FAO textural triangle and to the likely smectitic and Kaolinitic mineralogy. The CEC values are fairly consistent with this range of clay content [4].

The total nitrogen and organic carbon contents are very low ranging from $0.02-0.04 \%$ to $0.6-0.8$ $\%$ respectively indicating very low organic matter content that coincides with the amounts usually present in an arid climate. The available phosphorus, extracted with sodium carbonate buffered at $\mathrm{pH}$ 8.5 , dominantly varies between 3 and $5 \mathrm{ppm}$ with a few high figures up to11 ppm. Dominant amounts are deficient for most crops and questionable for cereals and grasses - Table 2 . The availability of phosphorus is critical to plant uptake because soil alkalinity $(\mathrm{pH} 8.5-9.0)$ causes fixation and/or formation of insoluble compounds. However, crops vary in response and therefore the requirement for fertilizers application need to be assessed by field trials against the particular crop of interest after determining soil reactions. 


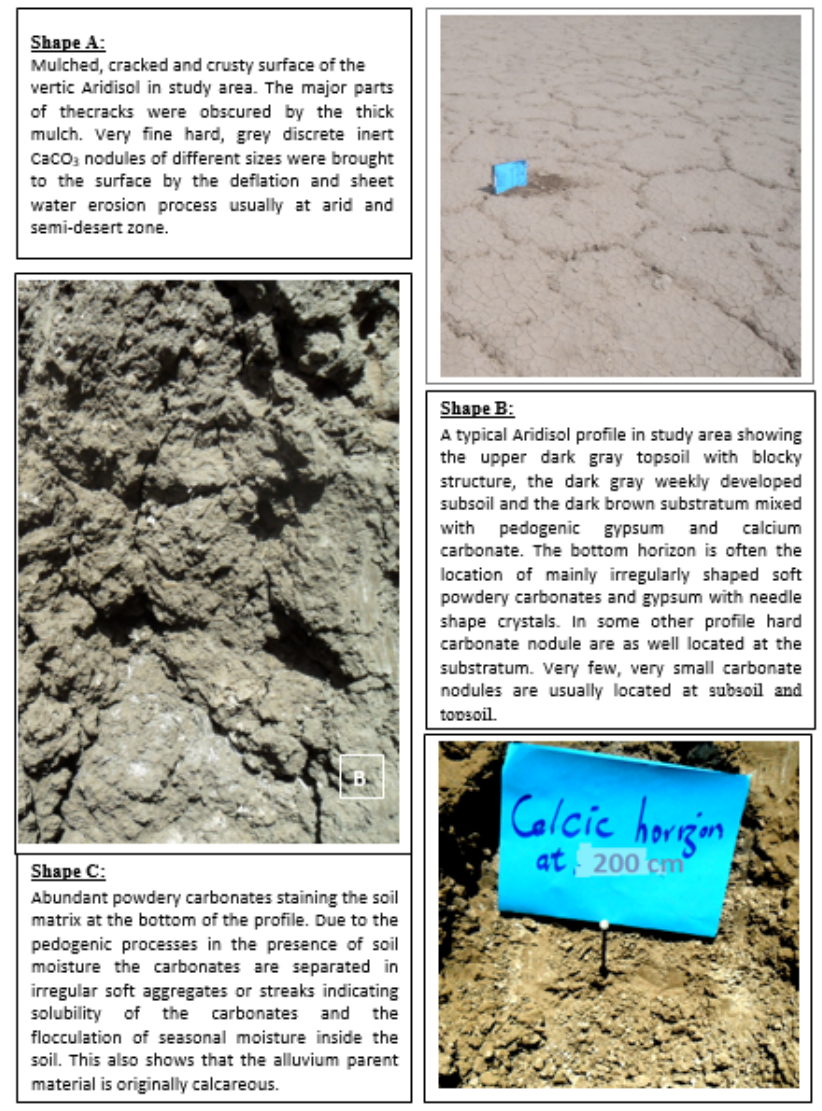

Figure 6: $\mathrm{CaCO} 3$ nodules, concretions and aggregates in Aridisols of Study area

Table 2: General Interpretation of Available Phosphorus Analysed by Olsen's Method

\begin{tabular}{|c|c|c|c|c|}
\hline \multirow{2}{*}{$\begin{array}{c}\text { Characteristic } \\
\text { crop demand }\end{array}$} & Examples & \multicolumn{3}{|c|}{ Indicative available phosphorus values } \\
\cline { 3 - 5 } & & Deficient & Questionable & Adequate \\
\hline Low P & Grass, cereals, soybean, maize & $<4$ & $5-7$ & $>8$ \\
\hline Moderate P & Lucerne, cotton, sweet corn, tomatoes & $<7$ & $8-13$ & $>14$ \\
\hline High P & Sugar beet, potatoes, celery, onions & $<11$ & $12-20$ & $>21$ \\
\hline
\end{tabular}

(Source: Landon, 1991)

The soil reaction is alkaline varying between mildly to strongly alkaline in almost all of the soils of the area. The pH-paste values of the saturation paste profile data ranges from 6.5-9.5 with a mean of 7.9. These values tend to be higher with the increase of the soil: water ratio (dilution effect). In this respect, $\mathrm{pH}$ values exceeding 9.0 are occasionally found in the suspension 1:5 soil: water ratio. Although generally the reaction of the soil matrix is slightly or moderately to highly calcareous, the laboratory measured $\mathrm{CaCO}_{3}$ content ranges from zero to $3.7 \%$. Higher contents are infrequent and occur in the substratum in some profiles.. Large fragments have little influence on soil fertility and it is the smaller particles, often found in the silt fraction, that are more important for irrigation agriculture [13]; [7].

The ECe of the saturation paste rarely exceeded $4 \mathrm{dS} / \mathrm{m}$ at $25^{\circ} \mathrm{C}$ which indicates a very low hazard of salinity in these soils? The types of salts, as given from analysis of the exchangeable and soluble cations and anions, are dominantly sulphates followed by chlorides. Bicarbonate is present in little amounts while carbonates are either as a trace or not detected. The exchange complex in soils of this area is fully saturated with basic cations of $\mathrm{Ca++}, \mathrm{Mg++}, \mathrm{Na}+$, and $\mathrm{K}+$. Exchangeable $\mathrm{H}+$ and $\mathrm{Al+++}$ (exchange acidity) is therefore, non-existing. 
The Cation Exchange Capacity CEC ranges from $40-70$ meq/100gr soil. Exchangeable Potassium and sodium are determined separately and results indicated that potassium, whilst adequate for agricultural purposes, is very low compared to sodium. The $\mathrm{Ca}+++\mathrm{Mg}++$ are calculated by difference between the CEC and exchangeable $\mathrm{Na}++\mathrm{K}+$, and therefore are not reported separately. This approach is adopted because of the occurrence of calcium sulphate in water adding more $\mathrm{Ca++}$ and $\mathrm{Mg++}$ to the soil solution which likely giving rise to erroneous estimates. The Sodium Adsorption Ratio (SAR) values are used to assess if there is any adverse effect of sodium in waters and soils.

\section{ENTISOLS}

\subsection{Surface Features and Morphological Properties}

Most of the soils of the Entisol order belong to the suborder Fluvents (from the Latin fluvius, river). These are brownish to reddish Entisols. They have formed in recent water-deposited sediments--primarily flood plains, fans, and deltas of rivers and small streams, but not in back swamps where drainage is poor (Figure 7). The age of sediments in which these soils form is usually very young, only a few years or decades. Under normal conditions Fluvents are flooded frequently, and deposited materials show signs of stratification---layers of a given texture alternated with layers of other textures. Most alluvial sediments, coming from eroding surfaces or stream banks, include very few amounts of organic carbon that are dominantly associated with the clay fraction. These soils do not occur under any specific vegetation type and may be found in most moisture or thermal regimes

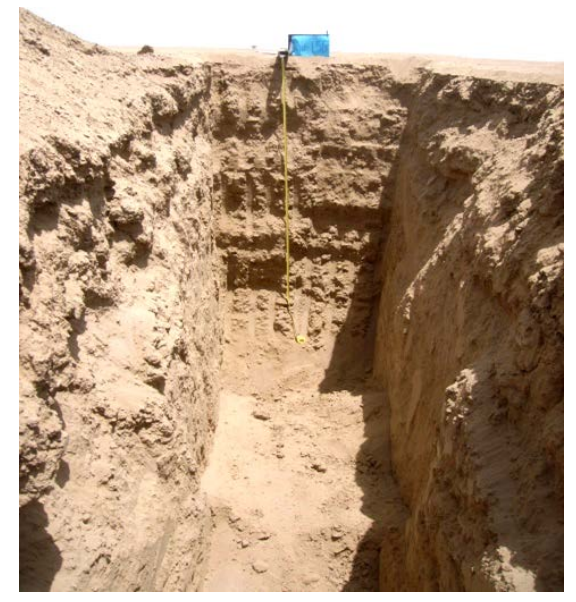

Figure 7: Entisols Profile (Typic Torrifluvents) at study area

\subsection{Physical properties}

The Entisols soils are relic high-level abandoned meanders and oxbows flanking both sides of Atbara River. The characteristic reddish recent alluvium soils developed in-situ from alluvial parent materials derived from Basement and sandstone formations, and also Tertiary volcanic rocks in the Atbara River catchment within Ethiopia. These rocks are rich in Ferro-magnesium minerals. The recent and semirecent soils appear to be much younger than the surrounding deposits and they are remnants of an alluvial landscape formation, probably during the Pleistocene and exposed to intensive alternating wet and dry periods [26]. The soils are very limited in extent and occupy relatively convex sites. Locally they are termed "Lebad". They are characterized by their brownish colour, silty clay textures, moderate CEC, relatively high permeability and moderate nutrient status. Soil management difficulties on these soils might result largely from sealed surfaces, hard consistence of the surface horizons, relatively high concentrations of salts and the relatively low natural fertility status. 


\subsubsection{Soil depth and Bulk density}

The depth of the non-Aridisols (recent and semi-recent deposits) is generally very deep at both southern and northern Parts of the area. No substratum rock materials were encountered at the alluvium soils sites. The bulk density of Entisols and Aridisols was not measured by the laboratory. However, data from geotechnical tests from the main canals at Study area indicated that the bulk density ranges from $1.3-1.7 \mathrm{~g} / \mathrm{cc}$ (oven dry moisture) and $1.4-1.8 \mathrm{~g} / \mathrm{cc}$ (at 1/3 bar moisture

\subsubsection{Soil structure and texture}

The surface is slightly hard dry, friable moist, sticky and plastic wet. It has a strong fine; medium and coarse sub-angular blocky structure. The subsoil is characterized by hard dry, friable moist, sticky and plastic wet consistence. The structure is dominantly weak, fine and medium sub-angular blocky. There is some surface cracking (cracks and tiny fissures $1-3 \mathrm{~mm}$ ) are observed but often the topsoil has a firm compacted surface with a sandy smear. The sandy clay loam surface and sandy clay subsoil and substratum have few to common $\mathrm{CaCO} 3$ and Fe-Mn concretions $(0.5-2 \mathrm{~cm})$ but as well clayey textures were noticed at some topsoil horizons. The soils are relatively high in sand content and there is less silt when compared with the Aridisols. The lower clay content results in a lower CEC than in the Aridisols although the mixed mineralogy typical of the alluvial sediments will contain the usual kaolinite and montmorillonite plus the iron oxide mineral goethite [4].

\subsubsection{Soil drainage and drainability}

Saturated hydraulic conductivity tests to indicate soil drainability were only conducted on Aridisols because it is known that wet Aridisols are essentially impermeable. Tests were carried out in-situ on the inferred least permeable horizon within $2.0 \mathrm{~m}$, by the inverse auger method. Table 3 summarises the hydraulic conductivity results.

Table 3:Saturated Hydraulic Conductivity of Entisols

\begin{tabular}{|c|c|c|c|}
\hline \multirow{2}{*}{ Profile number } & \multirow{2}{*}{ Soil unit } & \multirow{2}{*}{ Soil texture } & Average K m/day \\
\cline { 4 - 4 } & & & $\mathbf{1}$ \\
\hline 80 & $\mathrm{~A}$ & Clay loam & 1.09 \\
\hline 352 & $\mathrm{G}$ & Clay loam & 1.50 \\
\hline
\end{tabular}

Hydraulic conductivity results are regarded as indicative rather than precise. As regards interpretation, values below $0.2 \mathrm{~m} /$ day indicate slow - practically un-drainable soil and values up to $0.5 \mathrm{~m} /$ day suggest that either drainage may be required or irrigation should be applied in amounts and frequency consistent with a slow to moderate permeability, to avoid ponding. The substratum silt loam layers dominated by silt (silt about $50 \%$ of the particle sizes) could be the cause of the slow permeability of these soils. Although the control section of the Entisols soil is often dominated by coarse and fine loamy texture, it is normally separated by fine and coarse silty layers with more than $65 \%$ silt (Figure 7) that largely affect water movement and hence infiltration rate is controlled by these layers. Silty layers with fine and medium prismatic, angular and sub-angular blocky have an estimated hydraulic conductivity between $0.1-0.5 \mathrm{~m} \mathrm{day}^{-1}$. The field results fairly lie within this range indicating that the hydraulic conductivity is mainly controlled by these layers.

\subsubsection{Infiltration}

The infiltration rates should be interpreted as indicative rather than definitive and can vary considerably. Lack of a good correlation between infiltration and soil texture suggests that infiltration is more affected by soil structure, porosity, cracking or disturbance. Table 4 shows the infiltration test 
El Abbas. Doka M. Ali, Neil R. Munro and Karl Peter Kucera; Pedological Characterization of the Soils of Atbara and Gash Rivers Upper Atbara Project Area (Kassala State - Sudan). Advances in Image and Video Processing, Volume 5 No 6, December (2017); pp: 19-32

results for Entisols in Study area. Infiltration rates of between 0.5 and $2.0 \mathrm{~cm} / \mathrm{hr}$. are considered optimum for gravity irrigation. Rates up to $6.0 \mathrm{~cm} / \mathrm{hr}$. are increasingly marginal for successful gravity irrigation and rates beyond $6.0 \mathrm{~cm} / \mathrm{hr}$. are so high that very small basins or short furrows are required. Sprinkler irrigation is not restricted by high infiltration rates. Results show that the increasing clay content of the subsoil affected the slow $(0.2-0.5 \mathrm{~m} /$ day) hydraulic conductivities of these soils, whereas the sandy topsoil enhanced their moderate $(2.0-6.0 \mathrm{~cm} / \mathrm{hr}$.) infiltration rate.

Table 4: Infiltration Rate of Entisols

\begin{tabular}{|c|c|c|c|c|c|}
\hline \multirow{2}{*}{ Profile number } & \multirow{2}{*}{ Soil unit } & \multirow{2}{*}{ Soil texture } & \multicolumn{3}{|c|}{ Replicate cm/day } \\
\cline { 4 - 6 } & & $\mathbf{1}$ & $\mathbf{2}$ & $\mathbf{3}$ \\
\hline 296 & A & Clay loam & 3.0 & 2.0 & 2.7 \\
\hline 374 & G & Clay loam & 3.2 & 3.2 & 3.6 \\
\hline
\end{tabular}

\subsection{Available Water Capacity}

The available water capacities according to the soil units are shown in Table 13. Given that in semiarid zones where there is little accumulation of organic matter and where soil structures tend to be weakly developed, AWC is primarily related to soil texture [27]. This varies considerably within and between soils, so there is a corresponding variability of AWC as evidenced by the disparity between minimum and maximum values per soil unit. AWCs, calculated from the soil texture, range from 135 $\mathrm{mm}$ to $153 \mathrm{~mm}$ for the top $1.0 \mathrm{~m}$ of soil. The overall average is $148 \mathrm{~mm} / \mathrm{m}$ [3]. Based on all the study data arranged per soil unit the following classification of AWC can be derived (Table 5). Soil units $A$ and B (Atbara and Gash) have not been further separated according to their topsoil texture because the effect of sandy or loamy topsoil does not consistently affect the soil AWC; there is more variation due to other un-quantified factors (subsoil textures, structure, consistence, organic content, clay minerals assemblage). For irrigation design purposes groups of soil units can probably be characterised by the average of their AWC class, but with the proviso that at implementation the irrigation frequencies and applications may vary significantly about this average. Average minimum values are $55 \%$ to $65 \%$ of average values for the moderate AWC, low AWC and very low AWC classes.

Table 5:Classification of AWC $(\mathrm{mm} / \mathrm{m})$ of Entisols at Study area

\begin{tabular}{|c|c|c|c|c|c|}
\hline AWC class & Average & $\begin{array}{c}\text { Range of } \\
\text { average } \\
\text { values }\end{array}$ & $\begin{array}{c}\text { Range of } \\
\text { minimum } \\
\text { values }\end{array}$ & $\begin{array}{c}\text { Average } \\
\text { minimum } \\
\text { value }\end{array}$ & $\begin{array}{c}\text { Soil units } \\
\text { A and G }\end{array}$ \\
\hline Moderate & 170 & $160-180$ & $150-170$ & 160 & $\begin{array}{c}\text { AAtbara old alluvium -pit 335 } \\
\text { G Gash old alluvium -pit 194 }\end{array}$ \\
\hline
\end{tabular}

It is to be remembered that not all of the soil AWC is readily available to plants. Readily available water content was not measured but a rule-of-thumb is that it is about half to two-thirds of total AWC [10]; [27]

\subsubsection{Soil Taxonomic Classes of Aridisols And Entisols}

The soil types have been classified according to the Soil Taxonomy [16[. This classification is based on the soils' control section (usually the $0.25 \mathrm{~m}-1.00 \mathrm{~m}$ depth) and is shown in Table 6. The typical classification is given and also the classification of the soil phase where different from the classification of its soil unit. For example, a sodic phase of soil unit $\mathrm{G}$ will be classified differently from the typical $\mathrm{G}$. 
The soil properties that have been considered during the soil study to classify the soil units and their phases are: Topsoil and subsoil texture classes; Evidence of recent alluvial deposition; Degree of soil profile development; Presence, quantity and distribution of $\mathrm{CaCO}$; Levels and distribution of SAR; Levels and distribution of EC and Presence, nature and distribution of gypsum content.

Table 6: Theldentified Taxonomic Classes in the Study Area

\begin{tabular}{|c|c|c|}
\hline & & \\
\hline Soil unit class & Code & No. in class \\
\hline Vertic Haplocambids & VHC & 194 \\
\hline Typic Torrifluvents & TTF & 65 \\
\hline Typic Haplocambids & THC & 52 \\
\hline Fluventic Haplocambids & FHC & 33 \\
\hline Vertic Torrifluvents & VTF & 23 \\
\hline Typic Torripsamments & TTS & 7 \\
\hline Typic Haplocalcids & THD & 6 \\
\hline Number of classes in all pits & & $\mathbf{3 8 0}$ \\
\hline
\end{tabular}

\section{REFERENCES}

[1] Blokhuis, W.A., L.H.J. Ochtman, and K.H. Peters. 1968. Aridisols in the Gezira and Khashm el Girba clay plains, Sudan. Trans 8th Intern. Congress Soil Science, Bucharest Romania. VolV: 591-603.

[2] Blokhuis, W.A. 1993. Vertisols in the Central Clay Plain of the Sudan. PhD Thesis, Agricultural University Wageningen. 418 pages.Wageningen.

[3] Brady N. C. 1974. The Nature and Properties of Soils. 8th edition. Macmillan publishing Co. Inc. New York.

[4] Buursink, J.,1971. Soils of Central Sudan.PhD Thesis, Utrecht University. 248 p. Utrecht.

[5] DIU. 2014. Semi Detailed Soil Survey of Upper Atbara Irrigation Project Area. Volume 1: Main Report (Final Report). Dams Implementation Unit,Khartoum. Sudan

[6] FAO, 1970. Soil Survey of the Gash and Tokar Deltas. AGL:SF/SUD 15. Technical Report No. 4. Rome. Italy

[7] FAO, 1995.Integrated Plant Nutrition Systems. FAO Fertilizers and Plant Nutrition Bulletin - No.12

[8] FAO, 2006. Guidelines for Soil Description.4th edition. Rome

[9] Lahmeyer International. 2008. Development Options - Upper Atbara Irrigation Project, Technical Note 04 - 280212-3.doc. Dams Implementation Unit (DIU), Khartoum.

[10] Grossman et al., 1985. Application of pedology to plant response prediction For tropical Vertisols Proceeding of the Fifth international Soil classification workshop. Soil study Administration, Khartoum. Sudan

[11] Landon, R. (editor), 1991. Booker Tropical Soil Manual - A handbook for soil survey and agricultural land evaluation in the tropics and subtropics Paperback Edition, Longman Scientific Technical Co-published in USA with John Wiley \& Sons. Inc. New York

[13] Masdar, 1994. South Kassala Agricultural Development Project (SKAP).Ministry of Agriculture, Khartoum. 
El Abbas. Doka M. Ali, Neil R. Munro and Karl Peter Kucera; Pedological Characterization of the Soils of Atbara and Gash Rivers Upper Atbara Project Area (Kassala State - Sudan). Advances in Image and Video Processing, Volume 5 No 6, December (2017); pp: 19-32

[14] Mohamed, A. S. 1992/93. Effect of Phosphorus, Zn and Cu on wheat yield and nutrients content.Annual Report.GRS. Wad Medani, Sudan

[15] Newtech / HTSPE, 2009.Study of the Sustainable Development of Semi-Mechanized Rain-Fed Farming. Ministry of Agriculture, Khartoum

[16] Obeid, M. and Seif El Din.A., 1970. Ecological studies of the vegetation of the Sudan. Acacia senegal (L) wild and its natural regeneration, J. App.. Ecol. 7:502-518.

[17] Soil Survey staff. 2014. Keys to Soil Taxonomy, 12th edition. United States Department of Agriculture, (USDA). Washington,DC.

[18] Sogreah, 2007.Upper Atbara Irrigation Project. Project Review

[19] Sombroek, W. G. 1971. Aridisols of the World, Occurrence and Potential.Fourth International Soil Correlation Meeting (ISCOM), Lubbock, TX USA.Working Paper and Preprint No. 87/2. International Soil Reference and Information Centre (ISRIC). Wageningen, The Netherlands.

[20] SSA, 1973.Reconnaissance Soil Survey in the Upper Atbara Area.Hussam el Sayed Farah. SSA Report 48. Wad Medani.

[21] SSA, 1976. Exploratory Soil Survey of Kassala Province. A study of the physiography, soils, and agricultural potential.V. Van der Kevie and Ibrahim Buraymah.SSA Report, No. 73. Wad Medani.

[22] SSA, 1980. Semi-detailed soil survey and land suitability classification of Sitit area. Ahmed Abdel Raouf Khalil. SSA Report, No. 106. Wad Medani.

[23] SSA. 1983. Semi-detailed soil survey report of the Gash-Kassala Area. Abd el MoniemMohed Ahmed Kafeel. SSA Report, No. 123. Wad Medani.

[24] Swan, C.H. 1961. The Recorded Behaviour of the River Gash in the Sudan.Ministry of Irrigation and Hydro-electric Power, Khartoum.

[25] Van der Kevie, W. (Editor). 1976. Manual of land Suitability Classification for Agriculture, SSA, Wad Medani, Sudan.

[26] Whiteman, A.J., 1971. The Geology of the Sudan Republic, Oxford University Press,

[27] Williams, M.A.J. and Adamson, D.A. (eds.), 1982. A land between two Niles Quaternary geology and biology of the Central Sudan. Rotterdam: Bolkema

[28] Saxton, K. E., Rawls, W. J. 2006. Soil Water Characteristic Estimates by Texture and Organic Matter for Hydrologic Solutions. Soil Sci. Soc. Am. J. 70:1569-1578 (2006). Soil Science Society of America 677 S. Segoe Rd., Madison, WI 53711 USA

\section{ACKNOWLEDGEMENTS:}

The authors would like to acknowledge with great appreciation the effort extended by the supporting soil field and laboratory staff from College of Agricultural studies, LWRC lab team and by the soil field staff from Khartoum state Ministry of Agriculture. The supervision support provided by senior colleagues; Abdulkaareem O Fadl, Hashim Ali Dawoud, Fawzi M. Salih and Hussain Abu Zaid is highly appreciated. 